August 2006

\title{
Chronic-alcohol exposure alters IGF1 signaling in H9c2 cells via changes in PKC delta
}

\author{
Richard lla \\ Thomas Jefferson University \\ Michele Solem \\ Thomas Jefferson University
}

Follow this and additional works at: https://jdc.jefferson.edu/pacbfp

Part of the Medical Cell Biology Commons

\section{Let us know how access to this document benefits you}

\section{Recommended Citation}

Ila, Richard and Solem, Michele, "Chronic-alcohol exposure alters IGF1 signaling in H9c2 cells via changes in PKC delta" (2006). Department of Pathology, Anatomy, and Cell Biology Faculty Papers. Paper 7.

https://jdc.jefferson.edu/pacbfp/7

This Article is brought to you for free and open access by the Jefferson Digital Commons. The Jefferson Digital Commons is a service of Thomas Jefferson University's Center for Teaching and Learning (CTL). The Commons is a showcase for Jefferson books and journals, peer-reviewed scholarly publications, unique historical collections from the University archives, and teaching tools. The Jefferson Digital Commons allows researchers and interested readers anywhere in the world to learn about and keep up to date with Jefferson scholarship. This article has been accepted for inclusion in Department of Pathology, Anatomy, and Cell Biology Faculty Papers by an authorized administrator of the Jefferson Digital Commons. For more information, please contact: JeffersonDigitalCommons@jefferson.edu. 


\title{
Chronic-alcohol exposure alters IGF1 signaling in H9c2 cells via changes in PKC delta
}

\author{
Richard Ila, Michele Solem*
}

Department of Pathology, Anatomy and Cell Biology, Thomas Jefferson University, 1020 Locust Street, Philadelphia, PA 19107, USA

\begin{abstract}
This work was supported by the National Institutes of Health grant (R21AA013306-01A2) to Michelle Solem.
* Corresponding author. Tel.: 1-215-503-2681; fax: 1-215-923-2218.

E-mail address: michele.solem@jefferson.edu (M. Solem).
\end{abstract}

\begin{abstract}
Previously, we have demonstrated that chronic-alcohol exposure alters insulin-like growth factor 1 (IGF1) signaling in adult rat heart cells. This report examines the effects of alcohol in vitro on the expression of protein kinase $\mathrm{C}(\mathrm{PKC})$ alpha, delta, and epsilon using the embryonic heart cell line, H9c2, and how this may be linked to changes in IGF1 signal transduction. Western blot analyses of $\mathrm{H} 9 \mathrm{c} 2$ protein preparations demonstrate that there are significant increases in the total protein levels of PKC delta and epsilon after 4 days exposure to alcohol, and similar increases were found after 2 and 6 days exposure. In addition, there was a significant increase in PKC delta and epsilon in the membranal fractions and a decrease in the cytosolic fractions. No change was found in the expression or activity levels for PKC alpha. Chronic-alcohol exposure (100 mM, 4 days) increased the basal tyrosine kinase activity of the IGF1 receptor (IGF1R), and altered its rate of activation. Chronic-alcohol exposure also reduced the rate of Erk1/Erk2 activation by IGF1. Chronic alcohol blocked the proliferative effects of IGF1 on cell growth and reduced cell viability both in the presence and absence of IGF1, and this alcohol-induced reduction in cell viability was blocked using siRNA to inhibit PKC delta. In addition, a reduction in the amount of myosin light chain 2 was found in the alcoholexposed cells. In conclusion, chronic alcohol alters PKC delta and epsilon expression and activity, and suppresses the IGF1 signaling pathway in embryonic heart cell culture. Blockage of PKC delta expression using siRNA inhibits the suppressive effects of alcohol on cell viability.
\end{abstract}

Keywords: Insulin-like growth factor 1 (IGF1); Protein kinase C (PKC); IGF1 receptor (IGF1R); Extracellular-regulated kinase (Erk 44 and 42 kD, also referred to as MAP kinase); Small interfering RNA (siRNA)

\section{Introduction}

Recently, this laboratory has determined that in both adult rat heart cells and in H9c2 embryonic rat heart cells, selective inhibition by PKC alpha blocks the tyrosine kinase activity of the IGF1 receptor (Maniar et al., 2005). However, in cardiomyocytes from adult alcoholic rats, there is loss of IGF1stimulated PKC alpha activation as well as alterations in the IGF1 receptor activity (Pecherskaya et al., 2002). Since chronic-alcohol exposure is known to alter several different PKC isoenzymes levels of expression and activity, it may be that these proteins interfere with the normal role that PKC alpha plays in the IGF1 signaling pathway. Using H9c2 tissue culture, the following study was designed to determine if PKC plays a role in altering the IGF1 signaling pathway after chronic-alcohol exposure.

Several key studies using transgenic mice have demonstrated the importance of IGF1 in the heart's development and maintenance (DeLaughter et al., 1999; Liu and LeRoith, 1999; Montgomery and Schwartz, 1995). Homozygous IGF1-deficient mice are only half the weight of the wild types, and the vast majority of them die at birth. The hearts as well as other organs, including the liver, kidney, and brain

This is the authors' final version prior to publication in Alcohol 39(2006) 169-178. C 2006 Elsevier Inc. All rights reserved. For final published version see doi: 10.1016/j.alcohol.2006.08.006 
were found to be enlarged in these mice compared to their wild-type littermates (Liu and LeRoith, 1999). In another study, it was found that expression of IGF1 in a transgenic model initially induced physiologic hypertrophy, however, later in life a pathological condition developed characterized by decreased systolic performance and increased interstitial fibrosis (DeLaughter et al., 1999). IGF1 may also serve to inhibit cardiomyocytes from undergoing apoptosis following infarction (Chen et al., 2000; Wang et al., 1998). In primary neonatal cardiomyocyte culture, it was shown that IGF1 protects these cells from alcohol-induced cell death (Chen et al., 2000). IGF1 partially suppressed Bax induction, Caspase 3 activation, DNA fragmentation, and increased cardiomyocyte survival.

Many types of PKC isoenzymes have been detected in the heart. In adult rat cardiac tissue, the detection of the classical protein kinase $\mathrm{C}$ isoenzyme alpha, a $\mathrm{Ca}^{2+}$-requiring isoenzyme, and the novel protein kinase $\mathrm{C}$ isoenzymes delta and epsilon, which do not require $\mathrm{Ca}^{2+}$, accounted for the majority of PKC activity (Erdbrugger et al., 1997). Alcohol is known to modulate the expression and activity of several of these kinases in the heart and other tissues. Their roles in alcohol-associated heart disease are currently being identified (Chen \& Mochly-Rosen, 2001; Chen et al., 2001; Gray et al., 2004; Miyamae et al., 1998; Solem et al., 2000; Zhou et al., 2002). In this report, we examine how chronic-alcohol exposure results in changes in PKC delta and epsilon in embryonic heart cells, and how this may alter the IGF1 signaling pathway. We find that chronic alcohol reduces IGF1R activation as well as downstream Erk1/Erk2 activity. There is also a reduction in cell proliferation and cell viability after serum withdrawal by chronic alcohol. Since we find that there are changes in PKC delta and epsilon, we hypothesize that one or both of these isoenzymes may be involved. By inhibiting PKC delta expression with siRNA, this blocks the alcohol-induced reduction in cell viability and also reduces alcohol's inhibition of IGF1's protective effects. Finally, we measure proteins that are expressed during cardiac cell growth and hypertrophy. We find that IGF1 modestly increases the level of myosin light chain 2, and alcohol reduces the levels of this protein and blocks IGF1's effect. No changes are found in the expression levels of troponin C, beta-actin, or the IGF1 receptor.

\section{Methods}

\subsection{Materials}

Chemicals for buffers were purchased from Sigma Chemicals (St. Louis, MO); bovine serum albumin was purchased from Boehringer Mannheim Biochemicals (Indianapolis, IN); collagenase was purchased from Worthington Biochemicals (Lakewood, NJ). Phenylmethylsulfonyl fluoride (PMSF), leupeptin, aprotinin, and pepstatin were purchased from Sigma Chemicals (St. Louis, MO). IGF1 was purchased from R \& D laboratories, (Minneapolis, MN). All cell culture reagents and antibiotics were purchased from Gibco BRL (Gaithersburg, MD). Antibodies to PKC alpha, delta, epsilon, IGF1 receptor (beta subunit), beta-actin, myosin light chain 2, and troponin $\mathrm{C}$ were purchased from Santa Cruz Biotechnology (Santa Cruz, CA). Cell-Titer 96 Aqueous nonradioactive cell proliferation assay was purchased from Promega Corporation (Madison, WI). The siRNA (cat \# B-002000-UB-0115, sequence \#3) to block PKC delta, the siRNA (cat. \# M-04-0103-00) for rat PKC alpha, and the siRNA (cat. \# D-087950-01) for PKC epsilon were purchased from Dharmacon RNA Technologies (Lafayette, CO). In addition, the nonspecific control sequence (cat \# D-001210-01) was also purchased from Dharmacon. The transfection reagent TransIT-TKO transfection reagent (cat \# MIR2154) was purchased from Mirus Corp. (Madison, WI). $100 \%$ ethyl alcohol (alcohol) was a gift from the Thomas Jefferson University Pharmacy.

\subsection{H9c2 cell culture}

H9c2 rat embryonic cell culture (ATCC) was grown in DMEM with 10\% FBS, streptomycin/penicillin (Gibco BRL, Gaithersburg, MD) at 37C, 5\% $\mathrm{CO}_{2}$ as previously described (Maniar et al., 2005). Ethanolcontaining media $(100 \mathrm{mM})$ was changed daily, and the flasks containing the cells exposed to ethanol as well as the paired control flask were capped in order to prevent evaporation of ethanol from the media. 
This concentration of ethanol is within the range $(50-200 \mathrm{mM})$ that has previously been shown to alter PKC in tissue culture (Coe et al., 1996; Messing et al., 1991). For the experiments, only low passage cells $(<15)$ were used.

\subsection{Western analysis of PKC alpha, delta, and epsilon}

Western blotting was performed as previously described (Pecherskaya et al., 2002). Briefly, whole cell lysates from $\mathrm{H} 9 \mathrm{c} 2$ cells exposed to $100 \mathrm{mM}$ ethanol (2-6 days) were homogenized in cell lysis buffer (50 $\mathrm{mM}$ Tris, $\mathrm{pH} 7.5,150 \mathrm{~mm} \mathrm{NaCl}, 1 \%$ Triton X-100, $100 \mu \mathrm{M}$ phenylmethylsulfonyl fluoride, $25 \mu \mathrm{g} / \mathrm{ml}$ leupeptin, pepstatin, aprotinin, $2 \mathrm{mM}$ ethylenediaminetetraacetic acid, $1 \mathrm{mM}$ ethyleneglycotetraacetic acid) (Solem et al., 2000). To isolate the cytosolic and membranal fractions, the detergent was not included in the cell lysis buffer. The cells were homogenized by vortexing for $30 \mathrm{~s}$ in an Eppendorf tube and triturated 35 times using a 23-gauge syringe needle. The cell pellet containing the membranal portion was removed by quick centrifugation $(10,000 \times \mathrm{g}$ for $10 \mathrm{~min})$ and the lysate containing the cytosolic portion was immediately stored at $-20^{\circ} \mathrm{C}$. Next, the membranal fraction was dissolved in cell lysis buffer containing detergent (1\% Triton X-100). Protein concentrations were determined by using the Biorad (Hercules, CA) detergent-compatible protein assay kit. Protein samples $(50 \mu \mathrm{g})$ were heat denatured in sodium dodecyl sulfate (SDS)-Laemmli sample buffer and loaded onto 10\% SDS polyacrylamide gel electrophoresis (PAGE) gels for size separation. Molecular weights were determined by using molecular weight protein markers (Biorad, Hercules CA). The separated proteins were transferred to nitrocellulose and stained with antibody (1:300 dilution for $4 \mathrm{~h}$ ) to PKC alpha, delta, or epsilon (Santa Cruz Biotechnology, Santa Cruz, CA). The blots were washed $(3 \times$ at 30 min intervals using TBS containing tween-20 (0.1\%)) and stained with anti-rabbit conjugated IgG-HRP secondary antibody (1:3000 dilution for $30 \mathrm{~min}$ ) and then washed again $(3 \times)$. These blots were exposed to X-ray film (Fuji Photo Film, Tokyo, Japan) after a brief exposure to chemilluminescence buffer (Pierce Biotechnology, Rockford, IL). A determination was made of the amounts of these proteins detected by the film by scanning the X-ray film and analyzing the density of the bands using Scion Image (version 4.0.2). These experiments were repeated at least three times in order to achieve statistically significant results using the Student's $t$-test.

\subsection{Western analysis for the IGF1 receptor (beta subunit), beta-actin, troponin $C$, and myosin light chain 2}

Whole cell lysates from $\mathrm{H} 9 \mathrm{c} 2$ cells exposed to $100 \mathrm{mM}$ ethanol for 4 days were prepared as stated above. Western blots were performed on these samples using $50 \mu \mathrm{g}$ sample/ well, and the blots were probed with antibodies (1:500 dilution). A determination was made of the amount of protein in the samples by scanning the X-ray film and analyzing the density of the bands using Scion Image (version 4.0.2). For each protein examined, the experiments were repeated four times in four separate western experiments.

\subsection{Autophosphorylation of the IGF1 receptor}

H9c2 rat embryonic cells were used to examine the time course of IGF1 activation of its receptor in the presence and absence of alcohol exposure (100 mM, 2 days). The alcohol-containing media (DMEM + $10 \% \mathrm{FBS}, 100 \mathrm{mM}$ ethanol) as well as the control media (DMEM + 10\% FBS) were changed daily. Once the cells were confluent, the culture was serum-starved for $30 \mathrm{~min}$ at $37^{\circ} \mathrm{C}$ using serum-free DMEM media, after which the culture was exposed to IGF1 $(20 \mathrm{ng} / \mathrm{ml})$ for $5 \mathrm{~min}, 15 \mathrm{~min}, 30 \mathrm{~min}$, and $60 \mathrm{~min}$ at $37^{\circ}$ C. Cells were washed $3 \times$ using PBS, and then harvested in incubation buffer $(20 \mathrm{mM} \mathrm{Hepes} \mathrm{pH} \mathrm{7.4,}$ $150 \mathrm{mM}$ sodium chloride, $0.1 \%$ Triton X-100, 100\% glycerol, $200 \mathrm{mM} \mathrm{Na(o)-vanadate,} 10 \mathrm{mM} \mathrm{NaF}$, protease inhibitors (each at $5 \mu \mathrm{g} / \mathrm{ml}$ ) aprotinin, leupeptin, pepstatin). Rabbit polyclonal immunoglobulin $\left((p) \operatorname{tyr}(\mathrm{p})\right.$ tyr $^{1135 / 1136}$ ) from Biosource International (Carlsbad, CA) was used for these studies (Pecherskaya $\&$ Solem, 2000). This antibody recognizes the activated state of the IGF1 receptor beta subunit. The blots were standardized by measuring total protein levels of the IGF1 receptor (beta subunit) using a rabbit 
polyclonal antibody from Santa Cruz Biotechnology. A determination was made of the levels of tyrosine phosphorylation of the IGF1R of the normalized blots by scanning the X-ray film and analyzing the density of the bands using Scion Image (version 4.0.2). These experiments were repeated three times.

\subsection{Erk1/Erk2 phosphorylation}

The activities of Erk1/Erk2 before and after chronic-alcohol exposure (100 mM, 2 days) were measured using anti-phospho MAP kinase ((1:1000), Upstate Biotechnology, Lake Placid, NY) as previously described (Pecherskaya \& Solem, 2000). Briefly, cell lysates from H9c2 cells exposed to $100 \mathrm{mM}$ ethanol ( 2 days) and control cells were exposed to IGF1 $(20 \mathrm{ng} / \mathrm{ml}$ ) for $0 \mathrm{~min}, 5 \mathrm{~min}, 15 \mathrm{~min}, 30 \mathrm{~min}$, and $60 \mathrm{~min}$ at $37^{\circ} \mathrm{C}$. Samples $(50 \mu \mathrm{g})$ were run by SDS-PAGE $(12 \%$ acrylamide gel). Proteins were standardized using anti-MAP kinase ((1:500), Upstate Biotechnology). These experiments were repeated three times.

\subsection{Protein assay}

This assay was performed according to the manufacturer's instructions using the BioRad protein assay (detergent-compatible).

\subsection{Number of viable cells and cell growth rates}

Cell growth and viability were determined by measuring the growth rates using a hemocytometer and counting for viable cells. In brief, H9c2 cells were plated in 12-well dishes at a density of 10,000 cells/well in DMEM $+10 \%$ FBS for $3 \mathrm{~h}$. After the cells attached, the serum was reduced to $1 \%$. Cells were exposed to ethanol $(100 \mathrm{mM})$ in the presence/absence of IGF1 $(20 \mathrm{ng} / \mathrm{ml})$ as well as the control DMEM media, and the media was changed daily. Cell monolayers were isolated by trypsinization after 0,2 , and 4 days, rinsed once with PBS and counted using a hemocytometer (Sigma Corp., St. Louis, MO). The percentage of viable cells was determined by recording the number of cells that excluded trypan blue ( $0.4 \%$ solution) dye. The cells were photographed using an Olympus SC35 camera attached to an Olympus CK40 microscope.

\subsection{MTS metabolism in the presence of siRNA to PKC alpha, delta, and epsilon}

In addition to measuring cell viability using trypan blue exclusion, we measured the formation of formazan at $490 \mathrm{~nm}$ using the CellTiter 96 Aqueous One assay (Promega, Madison, WI). Approximately 10,000 cells/well were plated using 12-well polystyrene tissue culture plates. Next, the cells were transfected with siRNA to PKC alpha, delta, or epsilon (100 nM each) or with the nontargeting siRNA control $(100 \mathrm{nM})$ or mock transfected (no siRNA but with the TransIT transfection reagent) as previously described (Maniar et al., 2005). Next, the cells were incubated for $48 \mathrm{~h}$ in serum-free DMEM + antibiotics, DMEM + IGF1 $(20 \mathrm{ng} / \mathrm{ml})+$ antibiotics, DMEM + $100 \mathrm{mM}$ ethanol + antibiotics, or DMEM + $100 \mathrm{mM}$ ethanol + IGF1 $(20 \mathrm{ng} / \mathrm{ml})+$ antibiotics. After this transfection period, the cells were incubated in incubation buffer $\left(121 \mathrm{mM} \mathrm{NaCl}, 10 \mathrm{mM}\right.$ HEPES, $5 \mathrm{mM} \mathrm{NaHCO}_{3}, 4.7 \mathrm{mM} \mathrm{KCl}, 1.2 \mathrm{mM} \mathrm{KH}_{2} \mathrm{PO}_{4}, 1.2$ $\mathrm{mM} \mathrm{MgSO}_{4}, 0.125 \mathrm{mM} \mathrm{CaCl}_{2}, 10 \mathrm{mM}$ glucose at $\mathrm{pH}$ 7.4) for $1 \mathrm{~h}$. The cells were exposed to the MTS reagent (Promega Corp., 1:10 dilution) as described in the CellTiter 96 Aqueous One solution cell proliferation assay protocol. This is a colorimetric method that measures MTS (3-(4,5-dimethylthiazol-2yl)-5-(3-carboxymethoxyphenyl)-2-(4-sulfonphenyl)2H-tetrazolium) bioreduced by cells into a formazan product that is soluble in tissue culture medium and can be measured at $490 \mathrm{~nm}$. Increase in absorbance at $490 \mathrm{~nm}$ is an indicator of the number of living cells present in culture. Theses experiments were repeated five times and statistical significance was determined by ANOVA variance analyses.

\subsection{Statistics}

Results are expressed as the mean \pm S.E.M for each experimental condition. Analyses with $P<0.05$ were considered statistically significant using ANOVA variance analysis (Scheffe's multiple comparisons 
test). Statistical analyses of the PKC isoenzymes expression levels in whole cell lysates were done using the Student's $t$-test.

\section{Results}

Fig. 1a is an illustration of a western experiment measuring PKC alpha, delta, and epsilon total protein levels after 4 days of alcohol exposure $(100 \mathrm{mM})$ using whole cell lysates of H9c2 cells. Although PKC alpha was not affected by alcohol, there was a statistically significant increase in PKC delta $(58 \% \pm 7 \%$ above the control) and a statistically significant increase in PKC epsilon (59\% $\pm 7 \%$ above the control) in the alcohol-exposed cells. Graph 1a summarizes the results of three separate experiments. In addition, we measured PKC alpha, delta, and epsilon in whole cell lysates after 2 and 6 days. In 2 separate experiments, it is concluded that after 2 days exposure there was an increase in PKC delta $(44 \% \pm 9 \%$ above the control) and epsilon expression (70\% $\pm 4 \%$ above the control). After 6 days alcohol exposure, there was a continued increase for both PKC delta (50\% $\pm 6 \%$ above the control) and PKC epsilon (71\% $\pm 4 \%$ above the control). No change was found for PKC alpha. Next, we examined the distribution of PKC alpha, delta, and epsilon by fractionating the cell lysates into cytosolic (cyto) and membranal (mem) fractions (Fig. 1b) before and after exposure to alcohol $(100 \mathrm{mM})$. Although alcohol did not alter the distribution of PKC alpha (Fig. 1c), there was statistically significant increase in the membranal levels of PKC delta $(\mathrm{mem} /$ cyto ratio $=2.06 \pm .0 .04$ in the alcohol, $0.67 \pm 0.08$ in the control, results of three separate experiments), as well as significant increase in the membranal levels of PKC epsilon 0.9 (mem/cyto ratio = $1.06 \pm 0.02$ in the alcohol, $0.78 \pm 0.09$ in the control, results of three separate experiments). These results may indicate that alcohol increases the basal activity of these kinases, which is in agreement with other reports using adult heart cells (Miyamae et al., 1998; Solem et al., 2000; Zhou et al., 2002).

Previously, we have shown that in adult rats chronically exposed to high levels of alcohol, there is a $60 \%$ increase in basal IGF1 receptor tyrosine phosphorylation and a 27\% reduction in IGF1-stimulated IGF1 receptor activity in the isolated cardiomyocytes (Pecherskaya et al., 2002). Fig. 2 illustrates the rate of activation of the IGF1 receptor after chronic-alcohol exposure $(100 \mathrm{mM}, 2$ days $)$ in H9c2 cells. Exposure to IGF1 $(20 \mathrm{ng} / \mathrm{ml}$ for $0,5,15,30$, and $60 \mathrm{~min})$ activated the IGF1 receptor in both the control and alcohol-exposed cells, but the rate of activation was reduced in the alcohol samples (Graph 2). In addition, there was a detectable increase in basal receptor tyrosine kinase activity in the alcohol-exposed cells in all of the samples examined (three repeat experiments, normalized intensity of control $=0.16$, alcohol $=0.30$ ). The rate of phosphorylation for the control was $2.5 \%$ per minute and for the alcoholexposed cells it was $1.8 \%$ per minute, which represents a $28 \%$ decrease in IGF1R activation rate in the alcohol-exposed culture. In two separate experiments, acute exposure to alcohol (100 $\mathrm{mM}, 10 \mathrm{~min})$ completely blocked IGF1 R activation by IGF1 $(20 \mathrm{ng} / \mathrm{ml}, 10 \mathrm{~min})$, but did not increase the basal IGF1R activity (data not shown). This result is similar to what has been reported in other laboratories using various cell lines (Resnicoff et al., 1993, 1994).

Fig. 3 is a western experiment illustrating Erk1/Erk2 phosphorylation after IGF1 stimulation in control and alcohol-exposed H9c2 cells (100 mM, 2 days). Similar to the IGF1 receptor activation time course, the peak time point for Erk1/Erk2 activation was between $15 \mathrm{~min}$ and $30 \mathrm{~min}$ exposure to IGF1, and this began to decline after $60 \mathrm{~min}$. However, in the alcohol-exposed cells, there was a significant inhibition of the peak (only $68 \% \pm 9 \%$ on the control for Erk $1(44 \mathrm{kD}$ ); only $71 \% \pm 4 \%$ for Erk $2(42 \mathrm{kD})$ ), and the peak was increased to the 15 min time point in the alcohol-exposed cells.

Fig. 4 illustrates the effects of IGF1 and ethanol exposure on cell growth and viability of H9c2 cells. Cells were grown in DMEM $+1.0 \%$ serum in the presence of ethanol $(100 \mathrm{mM})$ and IGF1 $(20 \mathrm{ng} / \mathrm{ml})$ and photographed after 4 days (Fig. 4a). IGF1 increased cell proliferation over time. After 4 days in culture, 
IGF1 increased the cell number from $37,064( \pm 7,613)$ to $53,444( \pm 14,418)$. Alcohol exposure blocked this increase in cell growth to $38,138( \pm 9,923)$. These effects are graphically summarized in the corresponding graph (Fig. 4b). Fig. 4c illustrates the viability of these cells after 2 and 4 days of ethanol and IGF1 exposure using trypan blue exclusion assay. The reduced cell viability that was observed in the alcoholexposed samples was determined to be statistically significant compared to the IGF1-treated samples as determined by Scheffe's multiple comparisons test $(P<0.05)$.

Next, we measured the number of viable H9c2 cells after serum withdrawal using the CellTiter 96 Aqueous Non-Radioactive Cell Proliferation Assay. This assay was used to measure the effects of ethanol on IGF1's cell survival activity, and how PKC delta or epsilon may be involved. First, we determined using western experiments that after 2 days exposure to siRNA against PKC alpha (100 nM), PKC delta $(100 \mathrm{nM})$, or PKC epsilon $(100 \mathrm{nM})$ expression there was a $90 \%$ reduction in the expression of the corresponding protein in two separate experiments. No change in the level of beta-actin was found after 2 days exposure to siRNA delta $(100 \mathrm{nM})$, siRNA epsilon $(100 \mathrm{nM})$, or the scrambled siR-NA sequence $(100 \mathrm{nM})$. No change in the level of IGF1R was found after 2 days exposure to $100 \mathrm{nM}$ siRNA alpha (Maniar et al., 2005). In addition, no changes in the levels of expression of PKC alpha, delta, or epsilon were found after 2 days exposure to the nontargeting siRNA sequence $(100 \mathrm{nM})$. After determining the effectiveness of these siRNA sequences, we proceeded to evaluate the alcohol response in cell viability assays. Formazan formation was measured at $490 \mathrm{~nm}$ after $2 \mathrm{~h}$ incubation. These experiments were repeated 5 times. Fig. 4d is a graph illustrating the effects of siRNA to block PKC alpha, delta, and epsilon expression on formazan formation in serum-depleted cells exposed to IGF1 (20 ng/ml for 2 days), alcohol (100 mM, 2 days), or both IGF1 and alcohol. The absorbance was first normalized to the mock-transfected control (no IGF, alcohol exposure) response. In the mock-transfected cells, there was a 13\% increase in MTS metabolism after $48 \mathrm{~h}$ of IGF1 exposure compared to control media (DMEM alone). This increase was completely blocked in cells treated with siR-NA to PKC alpha (89\% of the mock-transfected control). There was no significant change in the IGF1 response in cells treated with siRNA to PKC delta or epsilon. This indicates that PKC alpha is required for IGF1's protective effects against cell death due to serum depletion. In mock-transfected cells, there was an 18\% decrease in MTS metabolism after alcohol exposure compared to the control. This decrease was completely blocked in cells treated with siRNA to PKC delta (108\% of the mock-transfected control). There was no significant recovery of the alcohol response in cells treated with siRNA to $\mathrm{PKC}$ alpha or epsilon. This indicates that PKC delta is involved in the suppressive effects of alcohol on cell viability. Similarly, PKC delta was also required for the inhibitory effects of alcohol in cells exposed both to IGF1 and alcohol. In mock-transfected cells, there was a 5\% decrease in MTS metabolism after IGF1 + alcohol exposure compared to the control. This suppressive effect was completely recovered after treatment with siRNA to PKC delta (111\% of the mocktransfected control). No significant change was found in cells treated with siRNA to PKC alpha or epsilon. Based on these results, it can be concluded that alcohol blocks IGF1's protective effects on cell viability, and that PKC delta is required for the inhibitory effects of alcohol.

Next, we examined the effects of IGF1 and alcohol on structural proteins involved in cardiomyocytes development (see Fig. 5). IGF1 has been shown to be a key growth factor in cardiomyocytes hypertrophy and protein synthesis (Foncea et al., 1997). The levels of expression of the IGF1 receptor (beta subunit), beta-actin, troponin $\mathrm{C}$, and myosin light chain 2 were examined in H9c2 cells after chronic-alcohol exposure (100 mM, 4 days), chronic IGF1 exposure (20 ng/ml, 4 days), or simultaneous exposure to both IGF1 and alcohol. Although chronic-alcohol exposure did not significantly affect the expression of the IGF1 receptor (beta subunit), beta-actin, or troponin C, it significantly decreased the expression of the myosin light chain protein as determined by Scheffe's multiple comparisons test. IGF1 slightly increased the expression of these proteins (29\% above the control), however, alcohol reduced its expression to $62 \%$ $\pm 6 \%$ of the control, and this effect was determined to be statistically significant by Scheffe's multiple comparisons test. Therefore, chronic-alcohol exposure influences the expression of a key structural protein that is regulated during IGF1-induced hypertrophic growth. Also, in the alcohol + IGF1 samples, there was 
a statistically significant reduction $(65 \% \pm 9 \%$ of the control). From these results, it can be gleaned that IGF1 modestly increases the myosin light chain 2-protein expression, and that alcohol reduces its expression in the presence or absence of IGF1.
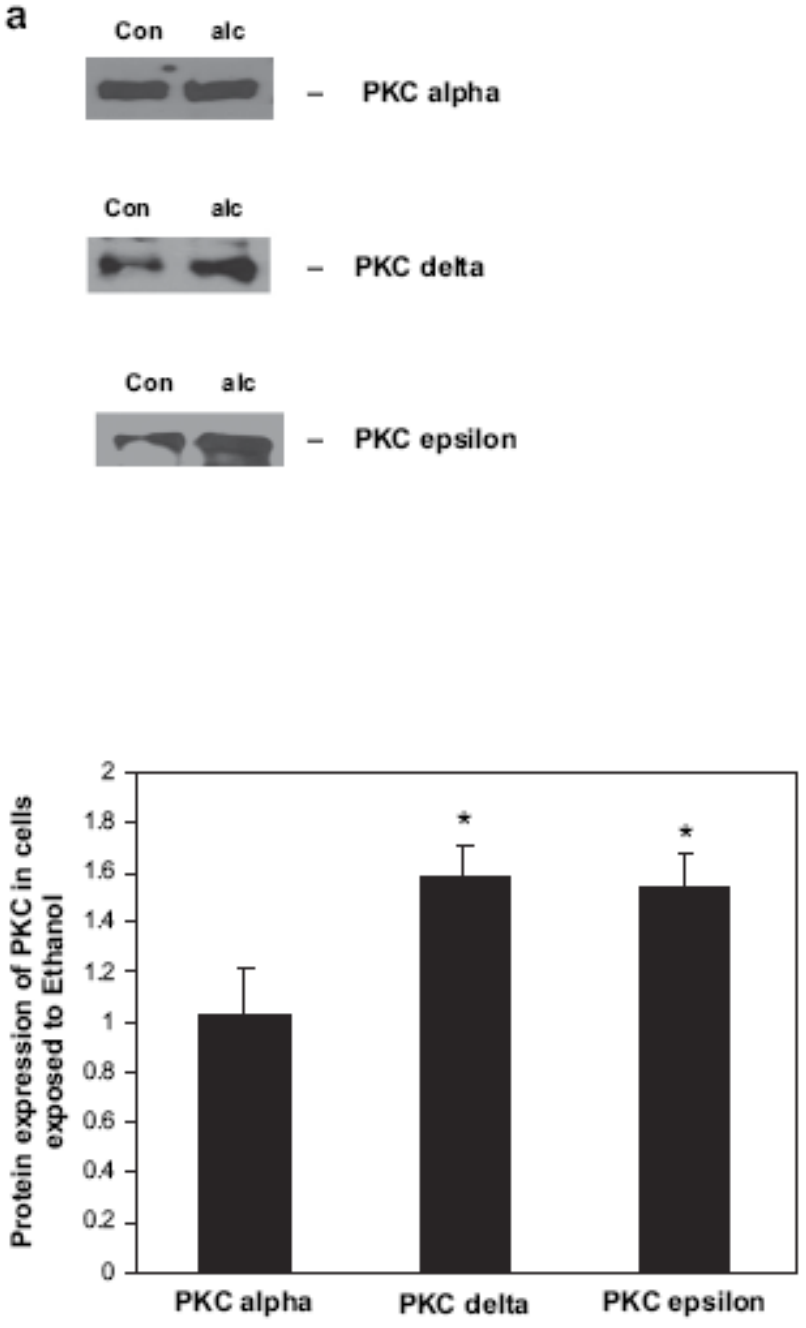

b

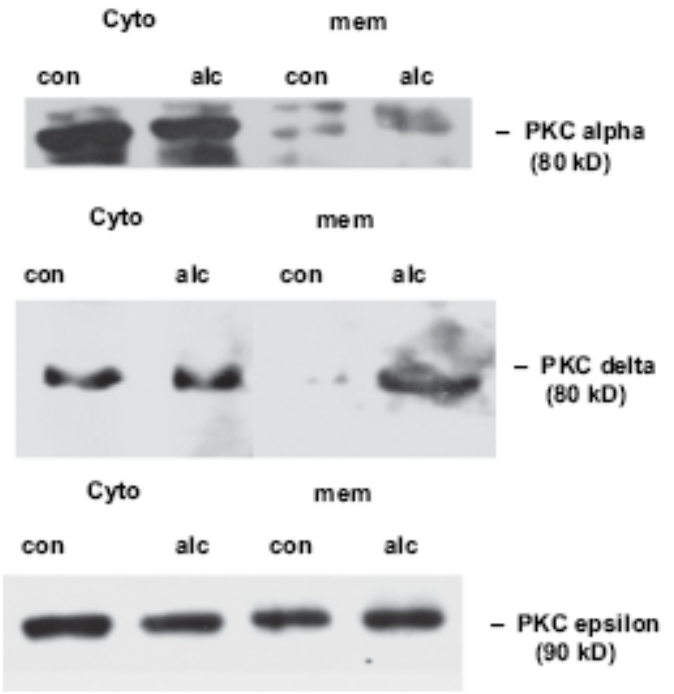

C

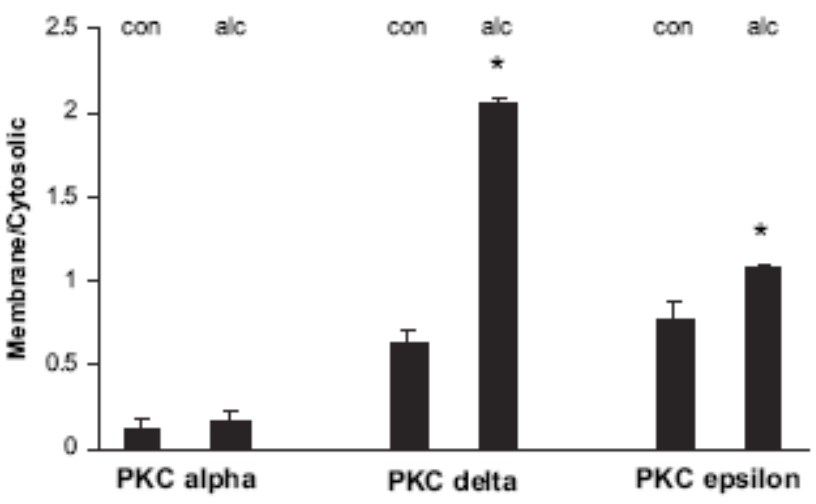

Fig. 1. PKC alpha, delta, and epsilon expression in H9c2 before and after exposure to 100 $\mathrm{mM}$ EtOH for 4 days (a). Cells were cultured in DMEM + 10\% FBS, antibiotics and the media was changed daily. In the EtOH treated cells, there was a 50\% increase in PKC delta as well as a $60 \%$ increase in PKC epsilon. No change was observed for PKC alpha in these experiments. These experiments were repeated three times. Graph (a) illustrates the summarized results of these experiments. * indicates statistically significant differences from the control (no alcohol treatment, $P<0.05$ ) in two-sided paired $t$-tests. In addition, experiments were performed to examine the cytosolic and membranal levels of these isoenzymes in order to determine if $\mathrm{EtOH}$ exposure promotes the translocation of these proteins to the membrane. (b) illustrates the results of fractionating PKC alpha, PKC delta and PKC epsilon. (c) In three separate experiments, it was determined that 100 $\mathrm{mM}$ EtOH causes a change in the membranal/cytosolic ratio for PKC delta from 0.67 $( \pm 0.008)$ to $2.06( \pm 0.004)$ and for PKC epsilon from $0.78( \pm 0.009)$ to $1.06( \pm 0.002)$. This suggests that $\mathrm{EtOH}$ promotes the translocation of $\mathrm{PKC}$ delta and epsilon, and that these isoenzymes may have altered activity due to $\mathrm{EtOH}$ treatment in $\mathrm{H} 9 \mathrm{c} 2$ cells. Statistical 
analysis was performed using ANOVA variance analysis (* indicates statistically significant difference from the control $(\mathrm{P}<!$ 0.05)).
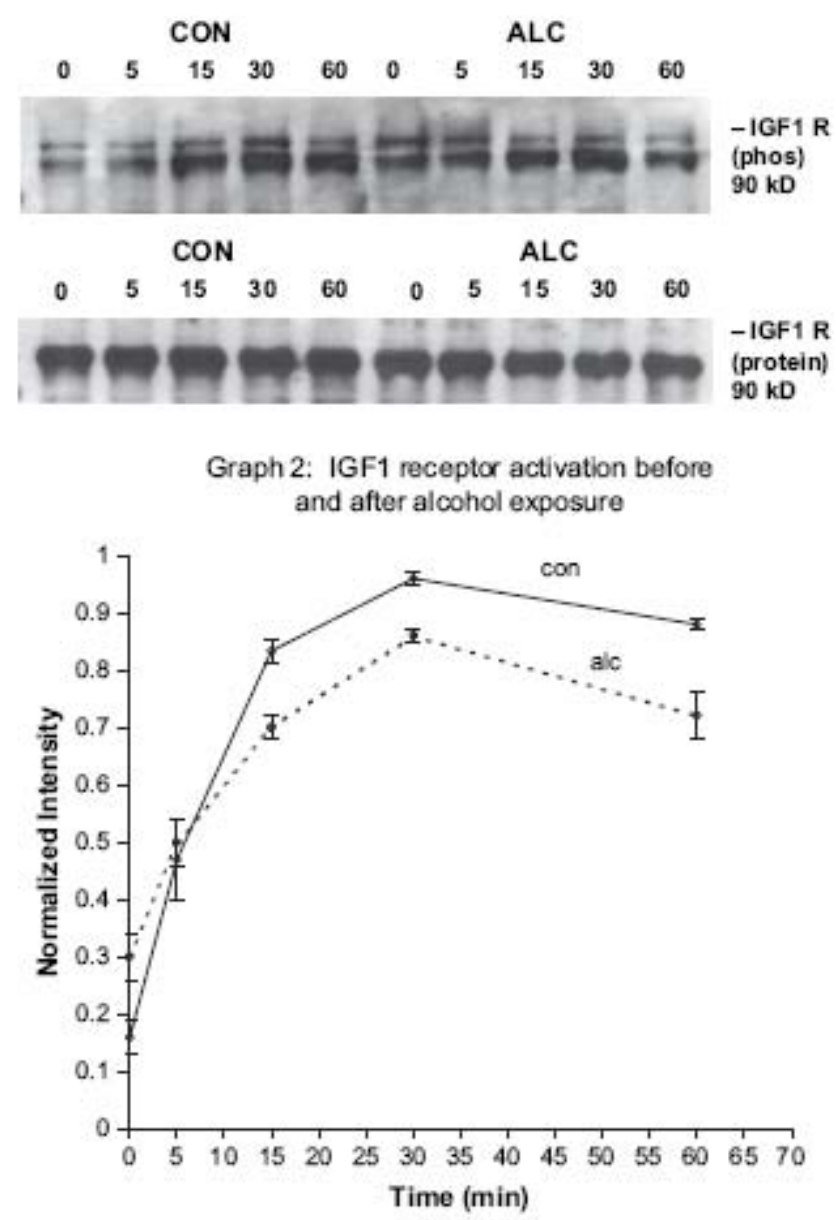

Fig. 2. Using the rat embryonic cardiac cell line, H9c2, it was demonstrated that exposure to $100 \mathrm{mM} \mathrm{EtOH}$ for 2 days resulted in a decrease in the rate of IGF1R activation. Cardiomyocytes were treated with IGF1 $(20 \mathrm{ng} / \mathrm{ml})$ for $0 \mathrm{~min}, 5 \mathrm{~min}, 15 \mathrm{~min}, 30 \mathrm{~min}$, and $60 \mathrm{~min}$ after exposure to EtOH. (1) $0 \mathrm{~min}$, (2) $5 \mathrm{~min}$, (3) $15 \mathrm{~min}$, (4) $30 \mathrm{~min}$, (5) $60 \mathrm{~min}$ (6) EtOH-exposure, 0 min (7) EtOH-exposure, 5 min (8) EtOH-exposure, 15 min (9) EtOH-exposure, $30 \mathrm{~min}(10) \mathrm{EtOH}$-exposure, $60 \mathrm{~min}$. This figure represents a Western blotting experiment. This blot was stripped and reprobed with IGF1R beta antibody (Santa Cruz) to standardize the experiment. The corresponding graph summarizes the results of three separate experiments. The phosphorylation levels were normalized to the total protein levels in each experiment in order to generate this graph. The solid line (-) represents the control (con); the dotted line (- -) represents alcohol exposure (alc). 

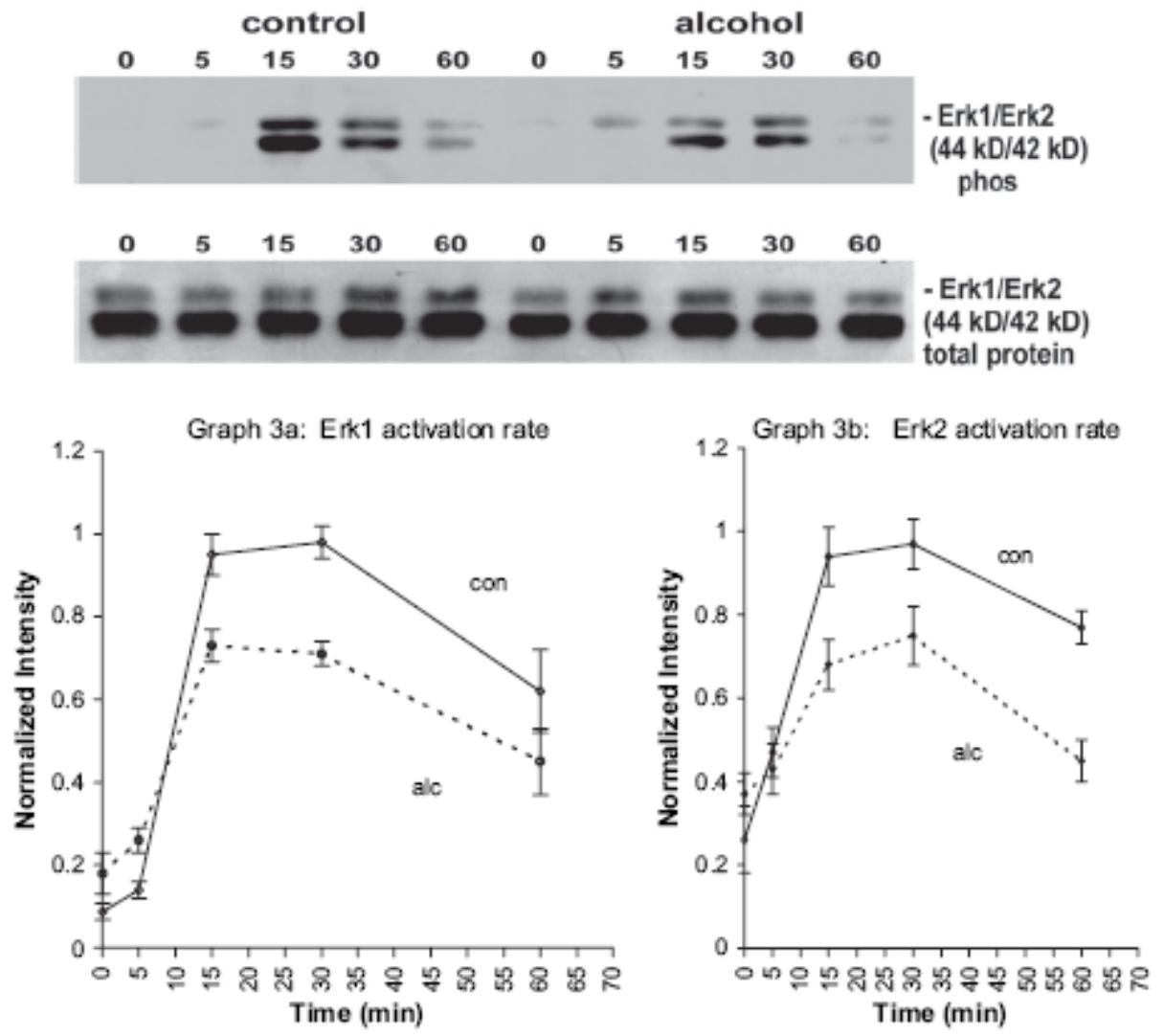

Fig. 3. Using the rat embryonic cardiac cell line, H9c2, it was demonstrated that exposure to $100 \mathrm{mM} \mathrm{EtOH}$ for 2 days resulted in a decrease in the rate of Erk1/Erk2 activation. Cardiomyocytes were treated with IGF1 $(20 \mathrm{ng} / \mathrm{ml})$ for $0 \mathrm{~min}, 5 \mathrm{~min}, 15 \mathrm{~min}, 30 \mathrm{~min}$, and $60 \mathrm{~min}$ after exposure to EtOH. (1) $0 \mathrm{~min}$, (2) $5 \mathrm{~min}$, (3) $15 \mathrm{~min}$, (4) $30 \mathrm{~min}$, (5) $60 \mathrm{~min}$ (6) EtOH-exposure, 0 min (7) EtOH-exposure, 5 min (8) EtOH-exposure, 15 min (9) EtOH-exposure, $30 \mathrm{~min}(10) \mathrm{EtOH}$-exposure, $60 \mathrm{~min}$. This figure represents a Western blotting experiment. This blot was stripped and reprobed with Erk1/Erk2 antibody (Upstate Biotechnology, NY) to standardize the experiment. The corresponding graphs summarize the results of three separate experiments. The phosphorylation levels were normalized to the total protein levels in each experiment in order to generate these graphs. The solid line (-) represents the control (con); the dotted line (- - -) represents alcohol exposure (alc). 


\section{EtOH}

Control

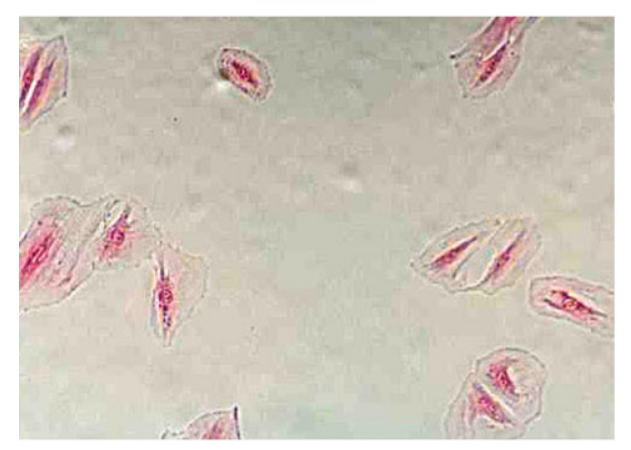

IGF1

(20 ng/ml, 48 hours)

(100 mM, 48 hours)

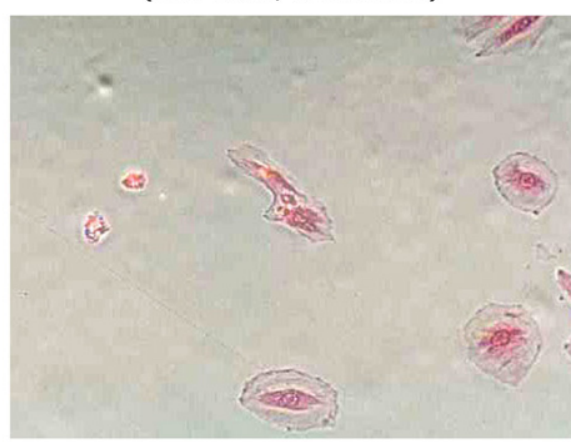

IGF1 + EtOH

(100 mM, 48 hours)
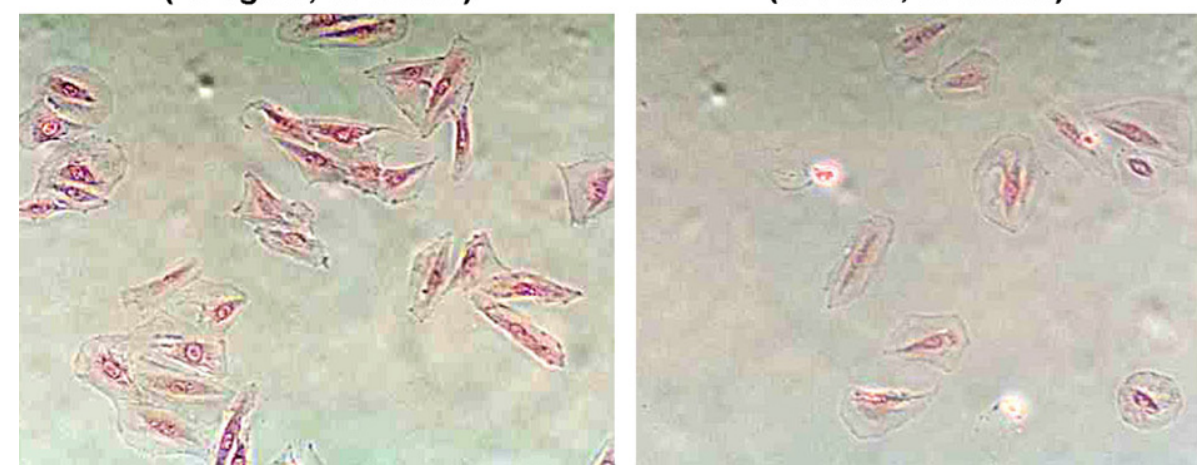

b
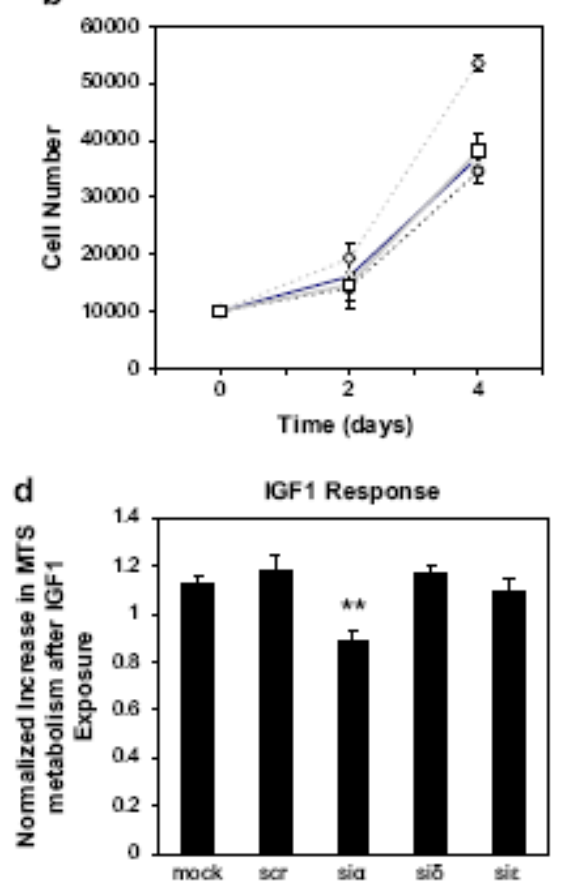

c

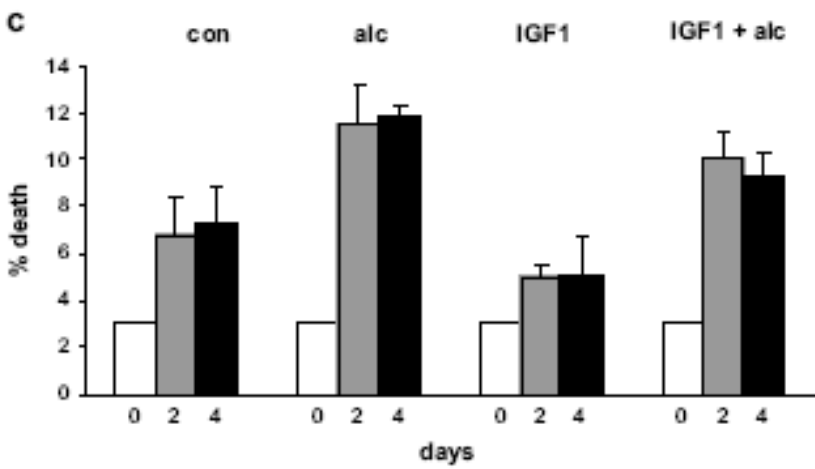

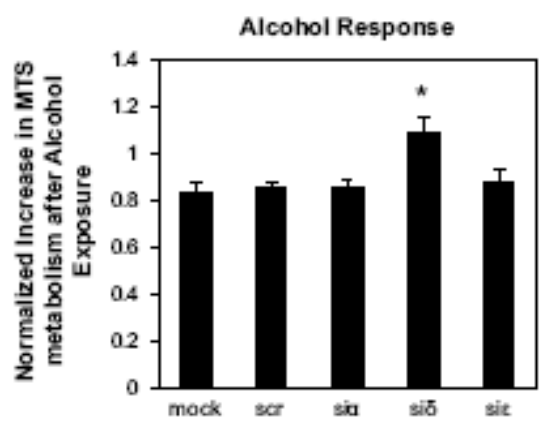

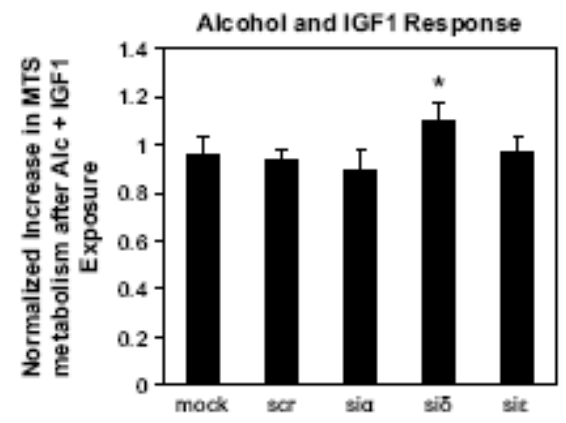

Fig. 4. The effects of EtOH and IGF1 on cell growth of H9c2 cells are illustrated. Cells were grown in DMEM $+1.0 \%$ serum in the presence of EtOH $(100 \mathrm{mM})$ and IGF1 (20 $\mathrm{ng} / \mathrm{ml}$ ) and photographed under phase contrast with an Olympus camera attached to an Olympus microscope. (b) graphically illustrates the growth rates of $\mathrm{H} 9 \mathrm{c} 2$ cells grown under the same conditions ( $\boldsymbol{\Lambda}=$ control), $(\square=100 \mathrm{mM} \mathrm{EtOH}),(\diamond=\mathrm{IGF} 1),(\mathrm{o}=\mathrm{IGF} 1+$ $100 \mathrm{mM} \mathrm{EtOH}$ ). (c) illustrates the viability of these cells grown in $1 \%$ serum after 48 and $96 \mathrm{~h} \mathrm{EtOH}$ and IGF1 exposure using the trypan blue exclusion method. (d) measures actively metabolizing cells grown in DMEM ( $0 \%$ serum) by measuring MTS metabolism before and after IGF1 $(20 \mathrm{ng} / \mathrm{ml})$ and alcohol $(100 \mathrm{mM})$ exposure for $48 \mathrm{~h}$ in cells mock 
transfected, transfected with the non-targeting siRNA sequence $(100 \mathrm{nM})$, transfected with siRNA alpha $(100 \mathrm{nM})$, siRNA delta $(100 \mathrm{nM})$, or siRNA epsilon. The MTS absorbance levels were normalized to the control (no IGF, alcohol). An increase in absorbance indicates that there are more actively metabolizing cells. * indicates that there is a statistically significant difference in the siRNA delta-treated cells compared to the mock and nontargeting siRNA treatment. ** indicates that there is a statistically significant difference in the siRNA alpha-treated cells compared to the mock and nontargeting siRNA treatment. Statistical significance at the 0.05 significance level was determined by ANOVA variance analysis (Scheffe's multiple comparisons test).
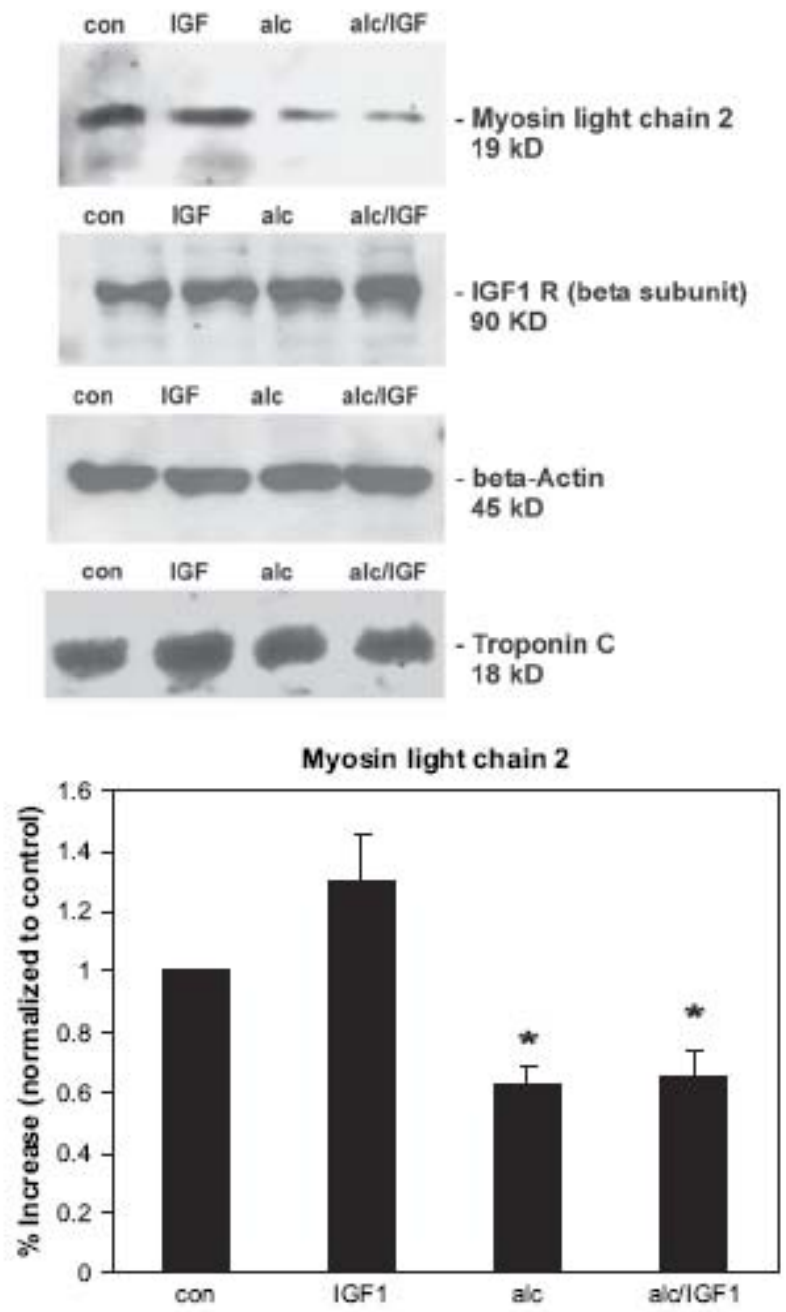

Fig. 5. Western analyses demonstrates that in EtOH exposed $\mathrm{H} 9 \mathrm{c} 2$ cells $(100 \mathrm{mM}, 4$ days), there is a reduction in myosin light chain protein by $40 \%$. In addition, EtOH exposure reduced myosin light chain protein expression in cells that were also exposed to IGF1 (20 ng/ml. 4 days). By itself, IGF1 (20 ng/ml, 4 days), modestly increased myosin light chain 2 . These results were statistically significant compared to the control as indicated by $*(P<0.05$ as determined by Scheffe's multiple comparisons test). No change was observed for the IGF1 receptor (beta subunit), beta-actin, or troponin $\mathrm{C}$ in EtOH-and IGF1-exposed cells compared to the control. 


\section{Discussion}

Several laboratories, including this laboratory, have reported that alcohol exposure alters PKC expression and activity in different cell lines and tissues (Coe et al., 1996; Messing et al., 1991; Miyamae et al., 1998; Solem et al., 2000). Therefore, we examined if chronic-alcohol exposure of H9c2 embryonic heart cells alters PKC alpha, delta, and epsilon expression and activity. These particular protein kinases are highly expressed in the heart (Erdbrugger et al., 1997). A key finding is that regular ethanol consumption causes sustained translocation of PKC epsilon in myocytes from rabbits, and this may contribute to the cardioprotective effect of ethanol against ischemia-reperfusion injury (Miyamae et al., 1998). Also in mice, moderate alcohol consumption induces sustained cardiac protection by activating PKC epsilon and Akt (Zhou et al., 2002). In cardiomyocytes from adult rats chronically exposed to alcohol, PKC epsilon was also found to be present at higher levels in the membranal fraction, and changes were also found in the regulation of the cardiac $\mathrm{Ca}^{2+}$ channel by PKC modulators in these animals (Solem et al., 2000). From these findings, it was inferred that alcohol-induced changes in PKC epsilon may be responsible for alterations in the cardiac $\mathrm{Ca}^{2+}$ channel. However, we did not test if PKC delta distribution was altered in these animals. Other reports demonstrate that the alcohol-induced changes in PKC are also found in neuronal cells (Coe et al., 1996; Messing et al., 1991). In PC12 cells, adaptation to alcohol involves increased expression of both PKC delta and epsilon (Messing et al., 1991). Ethanol also increases the abundance of L-type channels in these cells by at least two mechanisms; one involving increases in mRNA encoding the $\alpha_{1 \mathrm{C}}$ subunit, and the other involving a posttranscriptional mechanism that requires PKC delta (Walter et al., 2000). In NG108 cells, ethanol increases the amounts of PKC alpha, delta, and epsilon in these cells, and it is believed that the sensitivity of adenosine transport is due to a balance of PKA and protein phosphatase activities, which is regulated by PKC (Coe et al., 1996). Therefore, several different types of PKC are modulated by alcohol in the heart and in other tissues, and this effect may lead to cellular changes that are associated with PKC activity.

In this report, we demonstrate that in $\mathrm{H} 9 \mathrm{c} 2$ cells, both $\mathrm{PKC}$ delta and PKC epsilon are increased in their expression and activity levels after exposure to $100 \mathrm{mM}$ ethanol for 4 days. We suggest that the altered expression by one or both of these kinases may play an antagonizing role in the IGF1 signal transduction pathway. The increased presence of both PKC delta and epsilon in the membrane may lead to a chronic increase in the basal IGF1 receptor activity and a reduction in IGF1-stimulated responses that are normally coordinated by PKC alpha. This may also result in changes in the regulation of other IGF1 signaling proteins in the cascade, including Erk1/Erk2. Previous studies in other laboratories have demonstrated acute ethanol-induced inhibition of the IGF1 receptor signaling, including an inhibitory effect on the IGF1 receptor tyrosine kinase activity (Resnicoff et al., 1993, 1994; Seiler et al., 2000). This inhibition was highly significant in the NIH 3 T3 cells, which had a complete blockage of IGF1 receptor activation and had no change in IGF1 binding to the receptor with $100 \mathrm{mM}$ ethanol-exposure (Resnicoff et al., 1993). However, none of these studies have been performed on heart cells.

Additionally, we show that PKC delta is responsible for the inhibitory effects of alcohol on cell survival after serum withdrawal by measuring MTS metabolism. Treatment with siRNA for PKC delta blocked the suppressive effects of alcohol and completely restored IGF1's protective effects even in the presence of alcohol. This result supports the recent finding that demonstrates an involvement of PKC delta in apoptosis induced by cardiac ischemia and reperfusion injury (Murriel et al., 2004). Also, it was reported that PKC delta plays a role in mitochondrial-dependent apoptosis, and its presence in the nucleus may be required for its demonstrated role in apoptosis (DeVries et al., 2002). Apoptosis of cardiac myocytes has been observed during fetal development of the heart, during injury, and heart failure. Since hearts do not replicate in the adult animal, this loss may lead to permanent loss of cardiac function.

Previously, we have shown that in both the adult rat ventricular cardiomyocytes and H9c2 cells, acute exposure to IGF1 resulted in activation of the IGF1 receptor's internal tyrosine kinase, and this was completely blocked by the PKC alpha inhibitor, Gö6976 (Maniar et al., 2005). Additionally, RNA 
interference using siRNA-mediated gene silencing of PKC alpha inhibited IGF1 receptor activity and almost completely blocked PKC alpha expression. The conclusion of this study was that PKC alpha plays an essential role in the IGF1 signaling cascade, including the regulation of its receptor as well as key signaling proteins and IGF1-dependent gene transcription. This may be due to PKC alpha having a direct effect on the IGF1R activation by IGF1. Recently, it has been determined that over-expression of wildtype PKC alpha, but not betaII, delta, epsilon, or zeta induced hypertrophic growth of neonatal cardiomyocytes. In addition, wild-type PKC alpha was shown to induce extracellular signal-regulated kinase1/2 (ERK1/ 2), and dominant negative PKC alpha inhibited PMA-induced ERK1/2 activation (Braz et al., 2002). Here, we demonstrate that alcohol exposure reduces IGF1-stimulated Erk1/Erk2 activity. In addition, we measured proteins that are expressed during cardiac cell growth and hypertrophy. The results from these experiments indicate that IGF1 slightly increased the level of myosin light chain 2, however, alcohol reduced the expression of this protein and also blocked IGF1's effect. Future experiments are in progress to uncover the PKC delta-dependent mechanisms that may be associated chronic alcohol's effects in the IGF1-dependent hypertrophic growth response. Alcohol's effects on cardiac development may be linked in some way to changes in myosin light chain expression. Myosin light chain 2 has been found to play a function in the maintenance of cardiac contractility and ventricular chamber morphogenesis during mammalian cardiogenesis (Chen et al., 1998).

\section{Acknowledgments}

We appreciate the help of Ruchita Maniar, a previous graduate student from this laboratory, for her work on a few of the Western blot experiments. Thanks to Dr. Raphael Rubin for his discussions on the project and to Dr. John Pastorino for critical reading of this manuscript.

\section{References}

Braz, J. C., Bueno, O. F., De Windt, L. J., \& Molkentin, J. D. (2002). PKC alpha regulates the hypertrophic growth of cardiomyocytes through extracellular signal-regulated kinase1/2(ERK1/2). J Cell Biol 156, 905-919.

Chen, C., \& Mochly-Rosen, D. (2001). Opposing effects of delta and xi PKC in ethanol-induced cardioprotection. J Mol Cell Cardiol 33, 581-585.

Chen, D. M., Wang, L., \& Wang, P. H. (2000). Insulin-like growth factor I retards apoptotic signaling induced by ethanol in cardiomyocytes. Life Sci 67, 1683-1693.

Chen, J., Kubalak, S. W., Minamisawa, S., Price, R. L., Becker, K. D., Hickey, R., Ross, J., \& Chien, K. R. (1998). Selective requirement of myosin light chain 2v in embryonic heart function. J Biol Chem 273, 1252-1256.

Chen, L., Hahn, H., Wu, G., Chen, C. H., Liron, T., Schechtman, D., Cavallaro, G., Banci, L., Guo, Y., Bolli, R., Dorn, G., \& Mochly-Rosen, D. (2001). Opposing cardioprotective actions and parallel hypertrophic effects of PKC delta and PKC epsilon. Proc Natl Acad Sci USA 98, 11114-11119.

Coe, I. R., Yao, L., Diamond, I., \& Gordon, A. (1996). The role of protein kinase C in cellular tolerance to ethanol. J Biol Chem 271(46), 29468-29472.

DeLaughter, M. G., Taffet, G. E., Fiorotto, M. F., Entman, M. L., \& Schwarz, J. R. (1999). Local insulin-like growth factor I expression induces physiologic, then pathologic, cardiac hypertrophy in transgenic mice. FASEB J 13, $1923-1929$.

DeVries, T. A., Neville, M. C., \& Reyland, M. E. (2002). Nuclear import of PKC delta is required for apoptosis: identification of a novel nuclear import sequence. EMBO J 21, 6050-6060.

Erdbrugger, W., Keffel, J., Knocks, M., Otto, T., Philipp, T., \& Michel, M. C. (1997). Protein kinase C isoenzymes in rat and human cardiovascular tissues. Br J Pharmacol 120, 177-186.

Foncea, R., Andersson, M., Ketterman, A., Blakesley, V., Sapag-Hagar, M., Sugden, P. H., LeRoith, D., \& Lavandero, S. (1997). Insulin-like growth factor 1 rapidly activates multiple signal transduction pathways in cultured rat cardiac myocytes. J Biol Chem 272, 19115-19124.

Gray, M. O., Zhou, H. Z., Schafhalter-Zoppoth, I., Zhu, P., Mochly-Rosen, D., \& Messing, R. O. (2004). Preservation of baseline hemodynamic function and loss of inducible cardioprotection in adult mice lacking protein kinase $\mathrm{C}$ epsilon. $J$ Biol Chem 279, 3596-3604.

Liu, J. L., \& LeRoith, D. (1999). Insulin-like growth factor I is essential for postnatal growth in response to growth hormone. Endocrinology 140, 5178-5184.

Maniar, R., Pecherskaya, A., Ila, R., \& Solem, M. (2005). PKC alpha-dependent regulation of the IGF1 receptor in adult and embryonic rat cardiomyocytes. Mol Cell Biochem 275, 15-24.

Messing, R. O., Petersen, P. J., \& Henrich, C. F. (1991). Chronic ethanol exposure increases the levels of PKC delta and epsilon expression and PKC-dependent phosphorylation in clonal neural cells. J Biol Chem 266, 23428-23432. 
Miyamae, M., Rodriguez, M. M., Camacho, S. A., Diamond, I., Mochly-Rosen, D., \& Figueredo, V. M. (1998). Activation of epsilon protein kinase C correlates with a cardioprotective effect of regular ethanol consumption. Proc Natl Acad Sci USA 95(14), 8262-8267

Montgomery, C., \& Schwartz, R. J. (1995). Myogenic vector expression of insulin-like growth factor I stimulates muscle cell differentiation and myofiber hypertrophy in transgenic mice. J Biol Chem 270, 12109- 12116.

Murriel, C., Churchill, E., Inagaki, K., Szweda, L., \& Mochly-Rosen, D. (2004). Protein kinase C delta activation induces apoptosis in response to cardiac ischemia and reperfusion damage. J Biol Chem 279, 47985- 47991.

Pecherskaya, A., Rubin, E., \& Solem, M. (2002). Alterations in IGF1 signaling in cardiomyocytes from chronic alcoholexposed rats. Alcohol Clin Exp Res 26, 995-1002.

Pecherskaya, A., \& Solem, M. (2000). Insulin-like growth factor 1 activates PKC alpha-dependent protein synthesis in adult rat cardiomyocytes. Mol Cell Biol Res Commun 42, 741-747.

Resnicoff, M., Rubini, M., Baserga, R., \& Rubin, R. (1994). Ethanol inhibits insulin-like growth factor-1-mediated signaling and proliferation of C6 rat glioblastoma cells. Lab Invest 71(5), 657-667.

Resnicoff, M., Sell, C., Ambrose, D., Baserga, R., \& Rubin, R. (1993). Ethanol inhibits the auto-phosphorylation of the insulinlike growth factor 1 (IGF-1) receptor and IGF-1-mediated proliferation of 3T3 cells. J Biol Chem 268, $21777-21782$.

Seiler, A. E., Ross, B. N., Green, J. S., \& Rubin, R. (2000). Differential effects of ethanol on insulin-like growth factor-I receptor signaling. Alcohol Clin Exp Res 24(2), 140-148.

Solem, M., Almas, J., Rubin, E., \& Thomas, A. (2000). Changes in activity and regulation of the cardiac calcium channel (Ltype) by protein kinase $\mathrm{C}$ in chronic alcohol-exposed rats. Alcohol Clin Exp Res 24, 1145-1152.

Walter, H. J., McMahon, T., Dadgar, J., Wang, D., \& Messing, R. O. (2000). Ethanol regulates calcium channel subunits by protein kinase C delta-dependent and -independent mechanisms. J Biol Chem 275, 25717-25722.

Wang, L., Ma, W., Markovich, R., Lee, W. L., \& Wang, P. (1998). Insulin-like growth factor I modulates induction of apoptotic signaling in H9C2 cardiac muscle cells. Endocrinology 139, 1354-1360.

Zhou, H. Z., Karliner, J. S., \& Gray, M. O. (2002). Moderate alcohol consumption induces sustained cardiac protection by activating PKC-and Akt. Am J Physiol Heart Circ Physiol 283, H165-H174. 